\title{
Discussion on Causes for the Phenomenon of Fault in Private Economy in New China
}

\author{
Meiying Yang \\ School of Economics \& Management, Changchun University of Science \& Technology \\ Changchun 130022, China \\ \& Business School, Jilin University \\ Changchun 130012, China \\ E-mail: yangmy996@139.com
}

Received: July 2, $2011 \quad$ Accepted: July 18, $2011 \quad$ Published: December 1, 2011

doi:10.5539/ass.v7n12p136 URL: http://dx.doi.org/10.5539/ass.v7n12p136

Foundation Item: Periodical achievement of social sciences foundation item "Analysis of the path for public goods supply in Jilin Province from the perspective of overall planning” in Jilin Province (Item NO: 2011B397)

\begin{abstract}
Private economy has existed since the ancient times. As a result of differences in the social system, the existing patterns of the private economy have also had great changes, but the content and essence of the private economy has been unchanged all along the time. In the process of development of the private economy in the new China, the phenomenon of fault has ever occurred, which causes the national economy to be on the verge of collapse. Specifically speaking, during the twenty years prior to and following "the Great Cultural Revolution" as the benchmark, the economic condition was extremely horrible. It is quite necessary to conduct a research on causes for the phenomenon of fault, which may offer reference for the party in power and decision makers to avoid any mistake in the future and may make the national economy develop in a healthy and rapid way.
\end{abstract}

Keywords: Private economy, Phenomenon of fault, Cause

With proceeding of the reform and opening up in China, China is taking earthshaking changes. All industries thrive and the country is prosperous and the people are at peace. Chinese private economy takes the high road to go towards the great stage of economy in China from the surreptitious and discriminated role "born of concubine" and has gradually become a fresh troop for the Chinese nation to become prosperous and rise. However, development of the private economy is not plain sailing and the phenomenon of fault occurred during the twenty years prior to and following the "Great Cultural Revolution", bringing us a painful historical lesion. Today, when we review this phenomenon of fault and analyze the underlying causes for this phenomenon, we can still find out the clear-cut epic significance.

\section{Connotation and manifestation of the phenomenon of fault in Chinese private economy}

\subsection{Origin of the private economy}

Due to publicity of the official government, until now, it is generally acknowledged by both experts and scholars in study of private economy and formal public media that, Chinese private economy was born at the end of the 70 s in the Twentieth Century. According to the author, formation of this economy pattern can track back as early as to the late slave society in China, and runs through development process of multiple social patterns, such as, the slavery system, feudalism, semi-feudal and semi-colony system and socialist system, etc. In brief, the Chinese private economy made a start in the commodity economy and has existed since the ancient times, a sort of economy pattern that is common in the human society.

\subsection{Connotation of the phenomenon of fault in private economy}

The phenomenon of fault in private economy refers to the extinction of this economy pattern during a certain historical period that is caused as a result of particular historical environment and man-made elements in the developmental history of the private economy and the objective rule of productivity development is violated. The 
phenomenon of fault in private economy in the new China refers to extinction of the Chinese private economy during the period from 1957 to 1977 when the three transformations in China were just finished. This period was an empty period for Chinese private economy and the twenty years prior to and following this period is the period of "fault" that is mentioned here in this article.

\subsection{Manifestation of the phenomenon of fault in private economy}

During the twenty years when "fault" of private economy in China occurred, especially during the ten years of "the Great Cultural Revolution", we could not even find any trace of the private economy in the mainland China. During the first ten years, people might "privately conduct a business" secretly, and there were several private economic sectors. However, during the second ten years, everything was the same, specifically speaking, "The Great Proletarian Cultural Revolution" at the end of the spring and the beginning of the summer of 1966, "the activity to do away with the "four olds' and cultivate the "four news", "fight selfishness and repudiate revisionism". "Revisionism" mainly referred to the party of Khrushchev who run counter to Marxism and Leninism. In China, the major subject to be overthrown was the representative of "capitalism" --- Mr. Liu Shaochi. And the slogan was to "sweep away feudalism, capitalism and revisionism", and one of the central ideas was "privateness" and "capitalism". Then, "Great Unity" was required and "everything should go to the public". It was obvious that private enterprises had no way to survive. The history of "joint state-private ownership" had just been a history and the private economy withered to nothing at all. During that period, private enterprises thoroughly disappeared and were totally faulted. All what we could see was the whole-colored state-owned enterprises and people's commune and the economic patterns were state-owned economy and collective economy. In the history of the new China, it was with intention that the economic chain of the social development was disconnected to several loops and this important economic pattern of private economy was replaced. The twenty years indeed had brought a catastrophic attack on the nation that was born out of the old China and in which all industries thrived. Then, why we say that Chinese private economy was faulted for twenty years instead of fifteen years or twenty-five years? Mr. Deng Xiaoping has pointed out in "We Shall Expand Political Democracy and Carry out Economic Reform" that, "After the new China was founded, land reform and collectivization were conducted in Chinese rural areas and socialist reform was conducted in capitalism industries and commerce in urban areas, both of which were done well. After the year 1957, the thought of 'the left wing' began to gain ground and gradually occupied the upper hand. During the 'Great leap forward' in 1958, the whole country rushed into mass action into communalization. 'Large in size and collective in nature' was particularly emphasized and all ate from the same big pot, which brought about great disasters, no to speak of the 'Great Cultural Revolution'. After 1976 when the 'Fang of Four' was smashed, and during the following two years, the country almost still followed the mistake of "the left wing" until the year 1978. During the entire 20 years from 1958 to 1978, income of farmers and workers seldom increased, the living standard was low and the productivity was seldom developed." (Deng Xiaoping, 1993, p.115) It can be said that, the national economy during that period was almost on the verge of collapse.

\section{Causes for the phenomenon of fault in private economy}

It helps for healthy development of private economy in the future to make clear the major causes for the phenomenon of fault. Today, when we review matter-of-factly the history of the twenty years with the two viewpoints of "materialism and idealism", we summarize the following six major causes for fault of the private economy in China.

\subsection{After the new political power was established, the CPC distorted the standard to judge the socialist system}

The People's Republic of China was established in October 1949 and the new political power almost gained a stable ground for seven years' efforts. At the end of 1956, the economic policy of CPC was immediately adjusted. In order to express the thorough revolutionary nature and eradicate all capitalism elements (of course, privatization was prohibited), it was mistakenly believed that socialist was a brand-new social system and all traces about the old society and all related with capitalism should be eradicated, including theories that should be abandoned without exception, which was the only way to go consistent with the original intention of the CPC to lead the whole country in a revolution.

What is socialist? Deng Xiaoping clearly said in his conversation in the southern China in 1992 that, "The essence of socialist is to emancipate the productive forces, develop productivity, wipe out exploitation, eliminate polarization and ultimately achieve common prosperity." (Today Information, 2004) Deng Xiaoping opposed that everything should be distinguished by whether it was "capitalism" or "socialism". He pointed out that, judgment of gain and loss or success and failure of work should be mainly based on "whether it is helpful for development of productivity in the socialist society, whether it helps to strengthen the overall national strength of 
the socialist country, and whether it helps to improve the living standard of people." (Deng Xiaoping, 1993, p.372) At that time, the decision makers were determined to conduct a thorough revolution and to let the whole world know that China was a pure proletarian land. It was an expedient at a transitional period to stabilize the society and popular feelings to allow existence of privately-owned economy (or private economy and joint state-private ownership) at the beginning of the foundation of the nation. After the political power was established, we should not let the private economy continue to survive for this was the only way to prove that the $\mathrm{CPC}$ led the public go towards a socialist path. Therefore, "large in size and collective in nature" started, which resulted in fault of private economy.

\subsection{The ultra-left trend of thought among the executive leaders of the party in power made trouble}

After the "Great Cultural Revolution" came to an end and the "Gang of Four" fell from power, it was supposed that the private economy should be unbundled. However, due to particular domestic and foreign historical backgrounds, the executive leaders of the party in power were unable to inherit the quintessence of Marxism and Leninism. Instead, they comprehended the proletariat revolution theory in a rigid and doctrinal way, which caused us to lose a perfect opportunity to develop the private economy. Within the party, the CPC pushed forward the "two whatevers" without restraint to a large extent, which per se was not the viewpoint of materialism. Furthermore, Mao Zedong, founder of the People's Republic of China, said many times that, there was no one who did not make mistakes in his work, and he also had made mistakes. "Each sentence one says is correct and one is absolutely correct, which is impossible." (Deng Xiaoping, 1982, p.35) The CPC took a clear stand in the working conference that was held in March 1977 that, we had to insist on the strategy of "two whatevers", which made the "private economy" in which all industries thrived at that time to lose the perfect opportunity to revive. The "Great Cultural Revolution" was exactly the later years of Mr. Mao Zedong which rejected without exception all so-called "ideas of capitalism" and "symptoms of capitalism" and resolutely criticized all the ideas and symptoms of capitalism. Therefore, the whole country "turned pale at the mention of the private economy" and the ultra-left trend of thought extended the fault time and space of the private economy.

\subsection{The rigid thought and concept of national citizens}

Twenty years is almost one generation. The thought and concept of one person is likely to be changed, but once the thought and concept of a generation is formed, it is secure against assault. At the end of the 50s and the beginning of the 70s of the Twentieth Century, together with an entire 60s, it was almost one voice and one thought all over the country, that is, selfishness was shameful, selflessness was honorable, communistic society was the most ideal social pattern and any organization that had the property of private interests violated the theory of socialist. At that time, the slogan was everywhere that "the idea which suddenly came to mind should be resolutely fought". In the course of time, the thought and concept of the whole country became a national spirit and there was no one who ever thought of breaking through the single system of the national economy and no one who dared to have this idea, let alone daring to exercise this idea. It seemed that all wealth was public and owned by the country in China. No one was allowed to encroach on the wealth and the method and approach to create weal was defined in a unified way. In the eyes of the hundreds of millions of people, all of the socialist was perfect, and there was no flaw at all, and all was capitalism that was outside the scope of public ownership, nationalization and collectivism. All these capitalism elements should not be bred on the land of China. Led by this sort of thought and concept, it was impossible for the private economy to revive. During the twenty years, the thoughts and concepts of people were almost rigidified without exception.

\subsection{The single planned economy impeded revival of the private enterprises}

During the twenty years when the private economy was faulted, any product and commodity fell within the scope of planned economy. The theoretical world at that time thought that the market economy was an outcome of capitalism and was patent of capitalism. As a matter of fact, the market economy was developed earliest in the developmental history of human. Exchange between several axes and one sheep is a perfect example in which the two parties of exchange could freely make a deal so long as they would like to. Why the market economy can not exist together with socialist? "Planned economy does not equal to socialism and capitalism also has planned economy. Market economy does not equal to capitalism and socialism also has market economy. Both planned economy and market economy are economic means." (Deng Xiaoping, 1993, p.373) Particular emphasis on planned economy can only bring about economic rigidity and stagnation of the national economy and that all is done based on plan. At the beginning of the 70s in the Twentieth Century, Mao Zedong, the supreme leader of $\mathrm{CPC}$, also matter-of-factly "intended to expand economic and technical exchange between China and foreign countries, including economic and trade relations between capitalism countries, and even introduction of foreign 
investments and joint venture, etc. However, the condition did not allow for that at that time. The foreign countries blocked China. afterwards, under influences of the 'Gang of Four', 'the whole country worshiped foreign things and fawned on foreign countries' and 'national betrayal emerged', which made us isolated from the world." (Deng Xiaoping, 1993, p.127) Then, first of all, we were afraid of the market economy just as a tiger, and afterwards, when we intended to develop the market economy, the "Gang of Four" made troubles and placed obstacles in the way, which led to the single national economic system and depression in the national economy. Mr. Deng Xiaoping looked far ahead and aimed high and brought order out of chaos. He clearly pointed out, "The basic means of production belongs to the country, under the collective ownership and goes to the public. When the country becomes prosperous, the material and cultural living standards of the citizens are improved and continuously improved. Where is the disadvantage!" "No matter how the country is open, the public-owned economy is always the subject. Joint venture with foreign countries includes half of socialism. The actual benefits from joint venture are mostly possessed by us. There is nothing to be afraid of. It is the country and the people that benefit from the joint venture instead of capitalism." (Deng Xiaoping, 1993, p.91) On September 19, 2004, the Fourth Plenary Session of the Sixteenth Central Committee of the CPC promulgated "Decision of the Central Committee of CPC on Construction of Ruling Power of the Party", which clearly stipulates that, "We should deal with the relationship between the market mechanism and macro control in a correct way, insist on the rules of the market economy, play the fundamental role of the market in resource allocation to a large extent, strengthen and improve macro control of the nation and facilitate the national economy to be filled with vigor, efficiency and to run in a healthy direction." (Compilation Group, 2004, p.92) Thus, it can be seen that the new Central Committee of the CPC led by the general secretary of the President Hu Jintao attaches great importance to the market economy. To learn from the historical experiences is a security for success in the future.

\subsection{Unreasonable democratic mechanism spelled an end to the opportunity to rectify the wrong line}

It should be acknowledged that the period was quite democratic during which Mao Zedong, as the supreme leader of the CPC, led the large number of his followers who aided in founding the new China, marched from Jinggang Mountains to Yan'an, and then to Xibaipo and finally to Beijing. For birth of the new China, the supreme and his generals were on good terms with each other and everybody spoke without reserve and said all what they knew in the life of the CPC. They corrected mistakes if they had made any and guarded against them if they had not. They didn't put labels on people and didn't use a big stick. They achieved the purpose of going forward by uniting together through criticism and self-criticism. At that time, democratic centralism was a magic weapon of the CPC and there was little estrangement among the high leaders. Nonetheless, when the political power was consolidated and the personal prestige of Mao Zedong grew increasingly, the deep-rooted feudal thought that had a long history of several thousand years again silently encroached on this giant. The supreme commander ought to have absolute authority. At that time, whoever had any opposing suggestion to the "Great Leap Forward" and "large-scale making iron and steel", this person was supposed to oppose "the Three Red Banners". It was normal that Liu Shaochi put forward his own viewpoints on the great policies about the national welfare and the people's livelihood. However, "his three freedoms and one contract" as well as his "Taoyuan Experience" were labeled as the crime of repeating the old path of capitalism. Too much emphasis on centralization, ignorance on democracy or centralization in the name of democracy all had led to the phenomenon of the new China at that time, that is, one person alone had the say. The private economy at that time was unlikely to gain its ground. Once a nation and a political power lost its democratic mechanism, its policies and lines deviated from the original direction and those who were in power were unable to recognize that, the nation and the political power would never obtain the opportunity to make any revision. Thus, we say that the unreasonable democratic mechanism of the supreme leader group of CPC should burden a compelling obligation for the fault in the private economy in China from the end of the 50s to the 70 s in the Twentieth Century.

\subsection{Abominable international environment restrained connection of the disconnected chain in Chinese private} economy

Objectively speaking, establishment of the new China indeed had gained support and help from the Communist International represented by Stalin. And the socialist camp, indeed, had been greatly expanded owing to alliance of the new China. It is a pity that, after Stalin passed away, his successor Khrushchev was not on borrowing terms with the CPC, which quickly made the two countries and the two parties become enemies. The CPC believed that the Communist Party of the Soviet Union had deviated from the track of Marxism and had the trend of revisionism. The CPC took a clear-cut stand on opposing revisionism in the Soviet Union, which caused some advanced experiences of the Soviet Union to be totally repudiated. What they approved, the CPC opposed and what they opposed, the CPC upheld. All that was concerned with private ownership and private economy was 
repelled without exception. Hence, this aggravated implementation of the policy of closing the door to the foreign countries. As a consequence, China broke away from communication with capitalist countries in the western part of the world and separated cooperation with the Communist Party of the Soviet Union in the eastern socialist camp. For a time, the international environment was quite abominable, which directly restrained connection of the disconnected chain in Chinese private economy. On one hand, China was afraid that the "revisionism" might censure the CPC run counter to the Marxism and Leninism. On the other hand, China was worried that the western capitalism might encroach on the nation. Therefore, the country toughened its scalp to go forward since it believed that socialism was the only truth. In the final analysis, this violated the principle of Marxism of coming down to earth. Finally, it is ourselves who got the worst of it.

It is exactly the above specific Chinese national situation and particular environment at both home and abroad that led to fault in the private economy for a whole twenty years. This has made the national economy of China lag behind at least several decades compared with the world economy and has brought about immeasurable harm to the national strength of China. Thus, today it is quite necessary to discuss the phenomenon of fault in the private economy in China for the national responsibility does not allow us to follow the same old disastrous road. To be sure, causes for the phenomenon of fault in the private economy in China are quite complicated and we still need to make further explorations in terms of theory from the perspective of development, take the history as the mirror and offer reference for avoiding any mistake in the future and make the national economy develop in a healthy and rapid direction.

\section{References}

(1977). Editorial: To learn the document well to grasp the guiding principle. People's Daily, Red Flag Journal and Liberation Army Daily, Feb. 7.

(2004). Today Information, June 18.

Compilation Group. (2004). One Hundred Questions in Study Guides for "Decision" in the Fourth Plenary Session of the Sixteenth Central Committee of CPC. Beijing: Party Building Books Publishing House, 9.

Deng, Xiaoping. (1982). Selected Works of Deng Xiaoping (1975-1982). Beijing: People's Publishing House.

Deng, Xiaoping. (1983). Selected Works of Deng Xiaoping, Vol. 3. Beijing: People's Publishing House.

Deng, Xiaoping. (1993). Selected Works of Deng Xiaoping, Vol. 2. Beijing: People's Publishing House. 